\section{Hiep hiep hoera!!!}

De gz-psychologen bestaan twintig jaar! En we vieren dit met een jubileumnummer van $G Z$-psychologie. Twintig jaar oud, dat betekent dat het beroep de adolescentie voorbij is en verder op weg gaat naar volwassenheid. Dat gz-psycholoog al een volwassen beroep is geworden, blijkt uit de belangrijke en onmisbare plek die de gz-psychologen hebben ingenomen in de gezondheidszorg. Bij volwassen worden hoort ook het ontwikkelen van een eigen identiteit en daar is misschien nog wat meer tijd voor nodig. Dit lezen we onder andere in het artikel van Peter van Drunen, die gastredacteur was van dit speciale nummer. Hij interviewde een grote groep opinion leaders in het veld, over hoe het beroep er nu voor staat. Er blijkt zowel binnen als buiten het vakgebied onduidelijkheid over wat de gz-psycholoog kan en zou moeten kunnen. Ook wordt verschillend gedacht over wat de gz-psycholoog mag doen: eenvoudigere behandelingen of 'het echte werk'. Als we over een poos het 40 -jarig bestaan mogen vieren, zal deze identiteit vast duidelijker zijn en kampt het beroep vast met heel andere issues, een midlifecrisis wellicht? Waar was ik zelf twintig jaar geleden, bedacht ik mij, en wat wist ik toen van de gz-psycholoog? Ik was een jaar klaar met studeren en was net begonnen aan de opleiding tot psychotherapeut. Ik had een tijdje een onbetaalde werkervaringsplek bij een kleine polikliniek in een omgebouwd appartement in zo'n kenmerkende Bijlmerflat van toen. Ik wist nog niks, maar leerde er gelukkig veel, want alle psychische en psychosociale problemen kwamen daar samen, van PTSS na de Bijlmerramp tot klachten die door patiënten verklaard werden vanuit Winti. Van de gz-psycholoog had ik toen nog niet gehoord. In de jaren daarna kwam ik op volgende werkplekken de eerste lichtingen piogs en gz-psychologen tegen. Wat een verademing, al die supergemotiveerde, ambitieuze en degelijk opge-

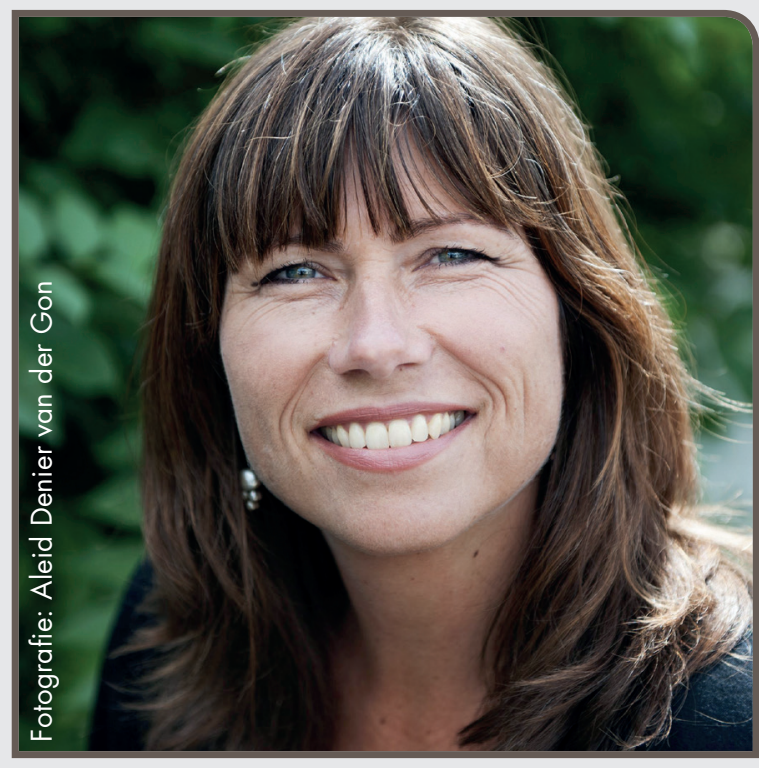

leide jonge mensen die evidence-based konden en wilden werken. Er waren toen nog veel minder opleidingsplekken dan nu en er werd om gevochten. Menigmaal zat ik in sollicitatiecommissies die piogs aannamen en meer dan honderd brieven voor één opleidingsplek was geen uitzondering. Het mooiste is om het hele traject mee te maken: de onervarenheid maar vaak grote gedrevenheid en ambitie van opleidelingen in het begin van de opleiding, en hun enorme ontwikkeling gedurende de twee intensieve opleidingsjaren. De opleiding levert goede gz-psychologen af, met voldoende kennis en vaardigheden. De komst van de beroepsgroep heeft veel goeds gebracht voor de kwaliteit van de patiëntenzorg. En inmiddels zijn de meeste van mijn collega's dan ook gz-psychologen.

Ook in dit nummer staat een dubbelinterview, met twee hoofdopleiders. In onze rubriek 'In gesprek met' pleit Arnoud Arntz, voorzitter van het Convent van Hoogleraren Klinische Psychologie, ervoor om de GZ-opleiding met de master Klinische Psychologie te integreren. En voor wie het niet meer allemaal op een rijtje heeft; bij het artikel van Peter van Drunen staat een overzichtelijke tijdlijn van hoe het beroep zich in de afgelopen twintig jaar ontwikkeld heeft. En die midlifecrisis komen we als gz-psychologen over twintig jaar ook vast goed door; is het niet door het aangaan van nieuwe uitdagingen, dan wel door een motor te kopen en naar het zonnige zuiden af te reizen.

Willemijn Scholten, hoofdredacteur 